\title{
Hepatitis B: treatment strategies and resistance
}

\author{
Vincent Soriano \\ From $16^{\text {th }}$ International Symposium on HIV and Emerging Infectious Diseases \\ Marseille, France. 24-26 March 2010
}

More than 350 million people worldwide are chronically infected with HBV. The prevalence is particularly high in South East Asia, Sub-Saharan Africa and South America. In developed regions, the rate of chronic hepatitis $B$ is declining mainly as result of universal HBV vaccine programs, although immigration from $\mathrm{HBV}$ endemic areas represents a continuous source of incident cases.

Viral load and HBV genotype influences the natural history of chronic hepatitis B and progression of liver fibrosis. Treatment must be considered for individuals with serum HBV-DNA above $2000 \mathrm{IU} / \mathrm{ml}$, given their increased risk of cirrhosis and liver cancer. Non-invasive tools for assessing liver fibrosis, such as elastometry (FibroScan) are rapidly replacing liver biopsy to guide treatment decisions.

Besides peginterferon, five nucleos(t)ide analogues (lamivudine, adefovir, telbivudine, entecavir and tenofovir) have been approved for the treatment of chronic hepatitis B; it is unlikely that any more will be available in the near future. Cross-resistance is common between all these drugs, although in different extent. Therefore, an adequate design of effective therapeutic strategies is crucial for long-term benefit using these drugs. Patients that experience virologic breakthrough or partial response to their primary therapy can often be successfully treated with a second nucleos(t)ide analogue, preferentially when the rescue intervention is done at early stages of failure. However, best strategies for preventing drug resistance include first-line use of the most potent antivirals with a high barrier to resistance (namely tenofovir or entecavir) and/or combination therapy. At this time, the use of lamivudine or adefovir as single agents in first-line therapy is no longer recommended, given their low-genetic barrier to resistance and weak activity, respectively.

The genes that encode the polymerase and envelope proteins of HBV overlap, so resistance mutations in

Infectious Diseases department, Hospital Carlos III, Madrid, Spain polymerase usually affect the hepatitis B surface antigen; these alterations affect infectivity, vaccine efficacy, pathogenesis of liver disease, and transmission throughout the population. Primary lamivudine resistance-associated mutations in HBV are now being seen in $10 \%$ of new HBV infections in Western Europe and North America.

A particular considerations merit the coinfection with HIV or the superinfection by delta virus. Specific guidelines for managing $\mathrm{HBV}$ in HIV+ individuals have been released (AIDS 2008, 22:1399-1410). The fixed combination of tenofovir plus emtricitabine (Truvada) is the preferred option in most HIV-HBV coinfected patients. The role of entecavir or telbivudine in this setting is hampered by the recognition of low anti-HIV activity and possibility of selecting resistance mutations in HIV. With respect to hepatitis delta, preliminary data suggest that potent nucleotide analogues as tenofovir may exert some benefit in a subset of individuals with chronic hepatitis delta, although data are too preliminary.

Published: 11 May 2010

\section{doi:10.1186/1742-4690-7-S1-123}

Cite this article as: Soriano: Hepatitis B: treatment strategies and

resistance. Retrovirology 2010 7(Suppl 1):123.

Submit your next manuscript to BioMed Central and take full advantage of:

- Convenient online submission

- Thorough peer review

- No space constraints or color figure charges

- Immediate publication on acceptance

- Inclusion in PubMed, CAS, Scopus and Google Scholar

- Research which is freely available for redistribution

Submit your manuscript at www.biomedcentral.com/submit
C Biomed Central 